\title{
Article \\ Suspected Miscarriage in the Experience of Emergency Medical Services Teams-Preliminary Study
}

\author{
Ewa Rzońca $^{1, * \mathbb{D}}$, Agnieszka Bień ${ }^{2} \mathbb{D}$, Grażyna Bączek $^{1} \mathbb{D}$, Patryk Rzońca $^{3} \mathbb{D}$, Michał Filip ${ }^{4}$ and \\ Robert Gałązkowski ${ }^{5}$ (D)
}

1 Department of Obstetrics and Gynecology Didactics, Faculty of Health Sciences, Medical University of Warsaw, 14/16 Litewska St., 00-575 Warsaw, Poland; gbaczek@wum.edu.pl

2 Chair of Obstetrics Development, Faculty of Health Sciences, Medical University of Lublin, 4-6 Staszica St., 20-081 Lublin, Poland; agnieszka.bien@umlub.pl

3 Department of Human Anatomy, Faculty of Health Sciences, Medical University of Warsaw, 5 Chałubińskiego St., 02-004 Warsaw, Poland; przonca@wum.edu.pl

4 Department of Obstetrics and Pathology of Pregnancy, Medical University of Lublin, 16 Staszica St., 20-081 Lublin, Poland; michalfilip@umlub.pl

5 Department of Emergency Medical Services, Faculty of Health Sciences, Medical University of Warsaw, 14/16 Litewska St., 00-575 Warsaw, Poland; robert.galazkowski@wum.edu.pl

* Correspondence: erzonca@wum.edu.pl; Tel.: +48-22-116-92-02

check for

updates

Citation: Rzońca, E.; Bień, A.; Bączek, G.; Rzońca, P.; Filip, M.; Gałązkowski, R. Suspected

Miscarriage in the Experience of Emergency Medical Services Teams-Preliminary Study. Int. J. Environ. Res. Public Health 2021, 18, 12305. https://doi.org/10.3390/ ijerph182312305

Academic Editor: Eusebio Chiefari

Received: 13 October 2021

Accepted: 20 November 2021

Published: 23 November 2021

Publisher's Note: MDPI stays neutral with regard to jurisdictional claims in published maps and institutional affiliations.

Copyright: (c) 2021 by the authors. Licensee MDPI, Basel, Switzerland. This article is an open access article distributed under the terms and conditions of the Creative Commons Attribution (CC BY) license (https:// creativecommons.org/licenses/by/ $4.0 /)$

\begin{abstract}
Vaginal bleeding and abdominal pain are symptoms indicative of a threat to pregnancy that prompt women to seek assistance from health care professionals. The purpose of the study was to present the characteristics of Emergency Medical Services (EMS) team interventions in cases of suspected miscarriage. The study involved a retrospective analysis of EMS team interventions in cases of suspected miscarriage carried out between January 2018 and December 2019 in Poland. Data obtained from Poland's National Monitoring Center of Emergency Medical Services included emergency medical procedure records and EMS team dispatch records in electronic format. The mean patient age was 30.53 years. Most were primiparous (48.90\%) and up to the 13th gestational week $(76.65 \%)$. The most commonly reported symptom was vaginal bleeding $(80.71 \%)$. EMS teams were most commonly dispatched in the winter (27.03\%), between 7 A.M. and 6:59 P.M. (51.87\%), in urban areas $(69.23 \%)$, with urgency code $2(55.60 \%)$, and in most cases, they transferred the patient to a hospital $(97.53 \%)$. The present study addresses very important issues concerning the characteristics of Polish suspected miscarriage cases handled by different EMS team types, in different locations (urban vs. rural areas), and concerning patients in a different obstetric situation (gestational week, gravidity, parity). Our findings suggest a need for further studies in this field and for gestational health promotion activities to be implemented, specifically including actions to reduce the risk of vaginal bleeding during pregnancy.
\end{abstract}

Keywords: Emergency Medical Service; vaginal bleeding; miscarriage; women

\section{Introduction}

Symptoms such as spotting or bleeding, amniotic fluid leakage, abdominal pain, or lower back pain may be indicative of a miscarriage [1,2], or early spontaneous pregnancy loss, whereby a live or dead embryo or fetus is passed before 22 weeks of pregnancy [3]. Vaginal bleeding is one alarming symptom occurring in many early pregnancies, which may precede a miscarriage $[4,5]$. In addition, the literature features many reports of the impact of a woman's psychological health on her experience of pregnancy loss. Notably, there is no single reaction to a miscarriage common to all women. Research demonstrates that women who had lost a pregnancy may experience sadness, shame, or guilt, in addition to symptoms of depression, grief, or anxiety, which may be transient or persist for a number of years. All of the above factors may affect the woman's health or the course of subsequent pregnancies [6-9]. 
As vaginal bleeding and abdominal pain are symptoms indicative of a threat to pregnancy, they prompt women to seek assistance from health care professionals, including via hospital emergency departments $[1,7,9,10]$. Importantly, these and other alarming symptoms may occur at any time during pregnancy and constitute a threat both to the woman's health and life [11,12]. In light of the constitutional duty to provide medical assistance to anyone who needs it, the National Emergency Medical Services system was founded in Poland. Its main task is to provide help to people experiencing a medical emergency posing an immediate risk to their life or health. The system is based on two independent pillars, i.e., Hospital Emergency Wards and Emergency Medical Services (EMS), including Polish Medical Air Rescue crews. To fulfill the State's constitutional duty to provide medical assistance to everyone who needs it, the Polish Emergency Medical Services (EMS) system was established. The main task of the EMS is to provide care to patients with severe or life-threatening emergencies. The system comprises hospital emergency departments and EMS teams, including air medical rescue teams. EMS teams are units within the system that are responsible for responding to emergencies and performing the necessary medical emergency procedures directly on scene and during patient transport to hospital. EMS teams are composed of physicians, emergency medical technicians, and nurses, and Polish EMS teams are classified as specialist, or physician-staffed, and basic, or non-physician-staffed [13].

The purpose of the study was to present the characteristics and to analyze interventions of EMS teams in cases of suspected miscarriage.

\section{Materials and Methods}

The present study comprised a retrospective analysis of Emergency Medical Services team interventions regarding suspected miscarriage in Polish women, conducted on the basis of data from the National Monitoring Center of Emergency Medical Services for the period of January 2018-December 2019. This is a national ICT system allowing for accepting emergency calls and event notifications from emergency numbers, dispatching EMS teams, logging medical events, including their location, preparing medical documentation, and managing calls [14]. Data obtained from the system included electronic records, namely emergency medical procedure documentation and EMS team dispatch documentation. The following information was obtained from the electronic records: date of call, location of call, details regarding the pregnant patient, clinical parameters of the patient, ICD-10 diagnosis codes assigned (International Statistical Classification of Diseases and Related Health Problems), emergency medical procedures applied, and other information on the interventions. The study received approval from the Polish Ministry of Health, which also supplied data for analysis. The Bioethics Committee of the Medical University of Warsaw in Poland reviewed the study protocol and confirmed that the retrospective nature of the study did not necessitate consent (statement AKBE/104/2021).

Cases classified under the following ICD-10 codes by the EMS team were analyzed: O03-spontaneous abortion, O03-other abortion, O06-unspecified abortion; where the gestational age did not exceed 22 weeks. We used the following exclusion criteria: medical assistance refusal, call cancellation, patient's absence on site, and gestational age above 22 weeks. Information on the gestational week was generated from the EMS medical documentation data which, in turn, are based on the information that EMS team members obtain from pregnant women and/or from the maternity notes. Of 2152 EMS team interventions in cases of suspected miscarriage, 1820 cases were ultimately included in the analysis based on the established criteria.

A statistical analysis of the data was conducted using the STATISTICA software, v. 13.2 (Tibco Software Inc., Palo Alto, CA, USA). Numbers (n) and percentages (\%) were used to describe qualitative data, and means (M) and standard deviations (SD) were used to report quantitative data. The Kolmogorov-Smirnov test and the Lilliefors test were used to analyze the normality of distribution for quantitative variables. The chi ${ }^{2}$ statistic was used to test statistically significant differences between qualitative variables. The non-parametric 
Mann-Whitney U-test was used to test differences between two independent groups and the Kruskal-Wallis test was used for more than two groups. Furthermore, the Spearman correlation coefficient was calculated. The significance level adopted in the study was $p<0.05$.

\section{Results}

The mean age of the women studied was 30.53 years. Most patients were primiparous $(48.90 \%)$, up to the 13 th gestational week $(76.65 \%)$, and had no history of miscarriage $(91.32 \%)$. The most reported symptom was vaginal bleeding $(80.71 \%)$. Detailed data are shown in Table 1.

Table 1. Characteristics of the women with suspected miscarriage.

\begin{tabular}{|c|c|}
\hline Age- $-\mathrm{M}(\mathrm{SD})$ & $30.53(6.76)$ \\
\hline \multicolumn{2}{|l|}{ Number of pregnancies-n (\%) } \\
\hline 1st & $890(48.90)$ \\
\hline 2nd & $393(21.59)$ \\
\hline 3rd or more & $537(29.51)$ \\
\hline Number of pregnancies-M (SD) & $2.08(1.42)$ \\
\hline \multicolumn{2}{|l|}{ Gestational week-n (\%) } \\
\hline$\leq 13$ weeks & $1395(76.65)$ \\
\hline$\geq 14$ weeks & $425(23.35)$ \\
\hline Gestational week-M (SD) & $10.79(4.15)$ \\
\hline \multicolumn{2}{|l|}{ Number of previous deliveries-n (\%) } \\
\hline 0 & $916(50.33)$ \\
\hline $1-2$ & $438(24.07)$ \\
\hline 3 or more & $466(25.60)$ \\
\hline Number of previous deliveries-M (SD) & $1.43(1.70)$ \\
\hline \multicolumn{2}{|l|}{ History of miscarriage- $-\mathrm{n}(\%)$} \\
\hline Yes & $158(8.68)$ \\
\hline No & $1662(91.32)$ \\
\hline \multicolumn{2}{|l|}{ Symptoms-n (\%) } \\
\hline Bleeding & $1469(80.71)$ \\
\hline Abdominal pain & $792(43.52)$ \\
\hline Spotting & $220(12.09)$ \\
\hline Contractions & $161(8.85)$ \\
\hline Vomiting & $60(3.30)$ \\
\hline Diarrhea & $19(1.04)$ \\
\hline
\end{tabular}

Table 2 shows the characteristics of EMS team interventions in cases of suspected miscarriage. The interventions occurred most often in the winter $(27.03 \%)$, between 7 A.M. and 6:59 P.M. (51.87\%), in urban areas (69.23\%). Most interventions were assigned urgency code $2(55.60 \%)$ and were carried out by a three-person $(52.20 \%)$, non-physician-staffed EMS team $(59.12 \%)$. The emergency medical procedure most commonly provided by EMS team members to the pregnant patients was blood pressure measurement $(94.84 \%)$, and further management typically involved patient transfer to hospital (97.53\%). 
Table 2. Characteristics of EMS team interventions.

\begin{tabular}{|c|c|}
\hline \multicolumn{2}{|l|}{ Time of Year-n (\%) } \\
\hline Spring & $438(24.07)$ \\
\hline Summer & $452(24.84)$ \\
\hline Fall & $438(24.07)$ \\
\hline Winter & $492(27.03)$ \\
\hline \multicolumn{2}{|l|}{ Time of call-n (\%) } \\
\hline 7 A.M.-6.59 P.M. & $944(51.87)$ \\
\hline 7 P.M.-6.59 A.M. & $876(48.13)$ \\
\hline \multicolumn{2}{|l|}{ Location of call-n (\%) } \\
\hline Urban area & $1260(69.23)$ \\
\hline Rural area & $560(30.77)$ \\
\hline \multicolumn{2}{|l|}{ Urgency code-n $(\%)$} \\
\hline Code 1 & $808(44.40)$ \\
\hline Code 2 & $1012(55.60)$ \\
\hline \multicolumn{2}{|l|}{ EMS team type-n $(\%)$} \\
\hline Non-physician-staffed & $1076(59.12)$ \\
\hline Physician-staffed & $744(40.88)$ \\
\hline \multicolumn{2}{|l|}{ EMS team composition-n (\%) } \\
\hline Two-person & $870(47.80)$ \\
\hline Three-person & $950(52.20)$ \\
\hline \multicolumn{2}{|l|}{ Medical emergency procedures-n (\%) } \\
\hline Blood pressure measurement & $1726(94.84)$ \\
\hline Pulse oximetry & $1686(92.64)$ \\
\hline Physical examination & 1267 (69.62) \\
\hline Intravenous cannulation & $939(51.59)$ \\
\hline Blood glucose measurement & $511(28.08)$ \\
\hline Intravenous medication & $439(24.12)$ \\
\hline Fluid therapy & $428(23.52)$ \\
\hline Analgesic treatment & $97(5.33)$ \\
\hline Gynecological examination & $81(4.45)$ \\
\hline \multicolumn{2}{|c|}{ Selected physical examination findings-M (SD) } \\
\hline Heart rate & $94.12(17.06)$ \\
\hline Mean arterial pressure & $99.68(14.76)$ \\
\hline Respiration rate & $16.05(4.18)$ \\
\hline Saturation & $97.93(1.21)$ \\
\hline Blood glucose & $114.64(37.10)$ \\
\hline${ }^{1}$ GCS & $14.96(0.57)$ \\
\hline${ }^{2}$ RTS & $11.95(0.30)$ \\
\hline \multicolumn{2}{|l|}{ Further management-n (\%) } \\
\hline Patient transferred to hospital & $1775(97.53)$ \\
\hline Patient left in place & $45(2.47)$ \\
\hline Total intervention duration (min) - $\mathrm{M}(\mathrm{SD})$ & $40.82(16.59)$ \\
\hline
\end{tabular}

${ }^{1}$ GCS-Glasgow Coma Scale; ${ }^{2}$ RTS-Revised Trauma Score.

Our analysis of associations between EMS team type and selected variables showed that non-physician-staffed EMS teams were more often dispatched with urgency code 2, with three responders per team. In addition, in non-physician-staffed team interventions, the pregnant patient remained on scene for a longer time, and the total duration was longer than in the case of interventions by physician-staffed EMS teams. An analysis of EMS calls to pregnant patients with suspected miscarriage from rural areas demonstrated that the patients tended to be older, and more interventions were assigned urgency code 1 . 
Patients from rural areas were also more often transported to hospital by the EMS team, and intervention duration was longer than in urban areas. These findings were statistically significant $(p<0.05)$ —see Table 3 .

Table 3. Analysis of the relationship between EMS team type and call location, and selected variables.

\begin{tabular}{|c|c|c|c|c|c|c|}
\hline \multirow[b]{2}{*}{ Variables } & \multicolumn{2}{|c|}{ EMS Team Type } & \multirow[b]{2}{*}{$p$-Value } & \multicolumn{2}{|c|}{ Location of Call } & \multirow[b]{2}{*}{$p$-Value } \\
\hline & $\begin{array}{l}\text { Non-Physician- } \\
\text { Staffed }\end{array}$ & $\begin{array}{l}\text { Physician- } \\
\text { Staffed }\end{array}$ & & Urban Area & Rural Area & \\
\hline Age-M (SD) & $30.57(6.94)$ & $30.47(6.51)$ & 0.9229 & $30.29(6.85)$ & $31.06(6.53)$ & 0.0283 \\
\hline \multicolumn{7}{|c|}{ Time of call-n (\%) } \\
\hline 7 A.M.-6.59 P.M. & $564(52.42)$ & $380(51.08)$ & \multirow{2}{*}{0.5735} & $663(52.62)$ & $281(50.18)$ & \multirow{2}{*}{0.3362} \\
\hline 7 P.M.-6.59 A.M. & $512(47.58)$ & $364(48.92)$ & & $597(47.38)$ & $279(49.82)$ & \\
\hline \multicolumn{7}{|c|}{ Location of call n (\%) } \\
\hline Urban area & 757 (70.35) & $503(67.61)$ & \multirow{2}{*}{0.2122} & - & - & \multirow{2}{*}{-} \\
\hline Rural area & $319(29.65)$ & $241(32.39)$ & & - & - & \\
\hline \multicolumn{7}{|c|}{ Urgency code-n (\%) } \\
\hline Code 1 & 417 (38.75) & $391(52.55)$ & \multirow{2}{*}{0.0000} & $537(42.62)$ & $271(48.39)$ & \multirow{2}{*}{0.0221} \\
\hline Code 2 & $659(61.25)$ & $353(47.45)$ & & $723(57.38)$ & $289(51.61)$ & \\
\hline \multicolumn{7}{|c|}{ EMS team composition-n (\%) } \\
\hline Two-person & $820(76.21)$ & $50(6.72)$ & \multirow{2}{*}{0.0000} & $597(47.38)$ & $273(48.75)$ & \multirow{2}{*}{0.5894} \\
\hline Three-person & $256(23.79)$ & $694(93.28)$ & & $663(52.62)$ & $287(51.25)$ & \\
\hline \multicolumn{7}{|c|}{ Further management-n (\%) } \\
\hline $\begin{array}{l}\text { Assistance provided, } \\
\text { patient transferred to } \\
\text { hospital }\end{array}$ & $1041(96.75)$ & $734(98.66)$ & 0.0099 & $1222(96.98)$ & $553(98.75)$ & 0.0251 \\
\hline Patient left in place & $35(3.25)$ & $10(1.34)$ & & $38(3.02)$ & $7(1.25)$ & \\
\hline $\begin{array}{l}\text { Intervention duration } \\
\quad(\min )-\mathrm{M}(\mathrm{SD})\end{array}$ & $42.55(16.88)$ & $38.35(15.87)$ & 0.0000 & $36.77(15.40)$ & $49.80(15.59)$ & 0.0000 \\
\hline
\end{tabular}

The statistical analysis conducted revealed a statistically significant association between the gestational week in the women with suspected miscarriage, to whom EMS teams were dispatched, and the history of miscarriage and urgency code $(p<0.05)$. Furthermore, there was a statistically significant association between the number of pregnancies and the number of deliveries in the women studied and their age, history of miscarriage, location of call, urgency code, and EMS team type $(p<0.05)$-Table 4 .

Table 4. Analysis of the relationship between gestational week, number of pregnancies and number of previous deliveries and selected variables.

\begin{tabular}{|c|c|c|c|c|c|c|c|c|c|c|c|}
\hline \multirow{2}{*}{ Variables } & \multicolumn{2}{|c|}{ Gestational Week } & \multirow{2}{*}{$p$-Value } & \multicolumn{3}{|c|}{$\begin{array}{l}\text { Number of } \\
\text { Pregnancies }\end{array}$} & \multirow{2}{*}{$p$-Value } & \multicolumn{3}{|c|}{$\begin{array}{c}\text { Number of Previous } \\
\text { Deliveries }\end{array}$} & \multirow{2}{*}{$p$-Value } \\
\hline & $\begin{array}{c}\leq 13 \\
\text { Weeks }\end{array}$ & $\begin{array}{l}14 \text { or } \\
\text { More }\end{array}$ & & 1st & 2nd & $\begin{array}{l}\text { 3rd or } \\
\text { More }\end{array}$ & & None & $1-2$ & $\begin{array}{l}3 \text { or } \\
\text { More }\end{array}$ & \\
\hline Age-M (SD) & $\begin{array}{l}30.57 \\
(6.86)\end{array}$ & $\begin{array}{l}30.39 \\
(6.44)\end{array}$ & 0.6413 & $\begin{array}{l}29.38 \\
(7.13)\end{array}$ & $\begin{array}{l}30.03 \\
(6.24)\end{array}$ & $\begin{array}{l}32.78 \\
(5.92)\end{array}$ & 0.0000 & $\begin{array}{l}29.47 \\
(7.10)\end{array}$ & $\begin{array}{l}30.06 \\
(6.25)\end{array}$ & $\begin{array}{l}33.04 \\
(5.86)\end{array}$ & 0.0000 \\
\hline \multicolumn{12}{|c|}{ History of miscarriage-n $(\%)$} \\
\hline Yes & $\begin{array}{c}94 \\
(6.74)\end{array}$ & $\begin{array}{c}64 \\
(15.06)\end{array}$ & 0.0000 & $\begin{array}{c}0 \\
(0.00)\end{array}$ & $\begin{array}{c}40 \\
(10.18)\end{array}$ & $\begin{array}{c}118 \\
(21.97)\end{array}$ & 0.0000 & $\begin{array}{c}40 \\
(4.37)\end{array}$ & $\begin{array}{c}71 \\
(16.21)\end{array}$ & $\begin{array}{c}47 \\
(10.09)\end{array}$ & 0.0000 \\
\hline No & $\begin{array}{c}1301 \\
(93.26)\end{array}$ & $\begin{array}{c}361 \\
(84.94)\end{array}$ & & $\begin{array}{l}890 \\
(100.0\end{array}$ & $\begin{array}{c}353 \\
(89.82)\end{array}$ & $\begin{array}{c}419 \\
(78.03)\end{array}$ & & $\begin{array}{c}876 \\
(95.63)\end{array}$ & $\begin{array}{l}367 \\
(83.79)\end{array}$ & $\begin{array}{c}419 \\
(89.91)\end{array}$ & \\
\hline
\end{tabular}


Table 4. Cont.

\begin{tabular}{|c|c|c|c|c|c|c|c|c|c|c|c|}
\hline \multirow{2}{*}{ Variables } & \multicolumn{2}{|c|}{ Gestational Week } & \multirow{2}{*}{$p$-Value } & \multicolumn{3}{|c|}{$\begin{array}{l}\text { Number of } \\
\text { Pregnancies }\end{array}$} & \multirow{2}{*}{$p$-Value } & \multicolumn{3}{|c|}{$\begin{array}{c}\text { Number of Previous } \\
\text { Deliveries }\end{array}$} & \multirow{2}{*}{$p$-Value } \\
\hline & $\begin{array}{c}\leq 13 \\
\text { Weeks }\end{array}$ & $\begin{array}{l}14 \text { or } \\
\text { More }\end{array}$ & & 1st & 2nd & $\begin{array}{l}\text { 3rd or } \\
\text { More }\end{array}$ & & None & $1-2$ & $\begin{array}{l}3 \text { or } \\
\text { More }\end{array}$ & \\
\hline \multicolumn{12}{|c|}{ Location of call-n (\%) } \\
\hline Urban area & $\begin{array}{c}975 \\
(69.89)\end{array}$ & $\begin{array}{c}285 \\
(67.06)\end{array}$ & 0.2678 & $\begin{array}{l}651 \\
(73.15)\end{array}$ & $\begin{array}{l}278 \\
(70.74)\end{array}$ & $\begin{array}{c}331 \\
(61.64)\end{array}$ & 0.0000 & $\begin{array}{c}673 \\
(73.47)\end{array}$ & $\begin{array}{l}301 \\
(68.72)\end{array}$ & $\begin{array}{c}286 \\
(61.37)\end{array}$ & 0.0000 \\
\hline Rural area & $\begin{array}{c}420 \\
(30.11)\end{array}$ & $\begin{array}{c}140 \\
(32.94)\end{array}$ & & $\begin{array}{l}239 \\
(26.85)\end{array}$ & $\begin{array}{l}115 \\
(29.26)\end{array}$ & $\begin{array}{c}206 \\
(38.36)\end{array}$ & & $\begin{array}{c}243 \\
(26.53)\end{array}$ & $\begin{array}{l}137 \\
(31.28)\end{array}$ & $\begin{array}{c}180 \\
(38.63)\end{array}$ & \\
\hline \multicolumn{12}{|c|}{ Urgency code-n $(\%)$} \\
\hline Code 1 & $\begin{array}{c}565 \\
(40.50)\end{array}$ & $\begin{array}{c}243 \\
(57.18)\end{array}$ & 0.0000 & $\begin{array}{l}357 \\
(40.11)\end{array}$ & $\begin{array}{l}189 \\
(48.09)\end{array}$ & $\begin{array}{c}262 \\
(48.79)\end{array}$ & 0.0015 & $\begin{array}{c}374 \\
(40.83)\end{array}$ & $\begin{array}{l}206 \\
(47.03)\end{array}$ & $\begin{array}{c}228 \\
(48.93)\end{array}$ & 0.0073 \\
\hline Code 2 & $\begin{array}{c}830 \\
(59.50)\end{array}$ & $\begin{array}{c}182 \\
(42.82)\end{array}$ & & $\begin{array}{l}533 \\
(59.89)\end{array}$ & $\begin{array}{l}204 \\
(51.91)\end{array}$ & $\begin{array}{c}275 \\
(51.21)\end{array}$ & & $\begin{array}{c}542 \\
(59.17)\end{array}$ & $\begin{array}{l}232 \\
(52.97)\end{array}$ & $\begin{array}{c}238 \\
(51.07)\end{array}$ & \\
\hline \multicolumn{12}{|c|}{ EMS team type-n $(\%)$} \\
\hline $\begin{array}{l}\text { Non-physician- } \\
\text { staffed }\end{array}$ & $\begin{array}{c}841 \\
(60.29)\end{array}$ & $\begin{array}{c}235 \\
(55.29)\end{array}$ & 0.0668 & $\begin{array}{l}555 \\
(62.36)\end{array}$ & $\begin{array}{l}222 \\
(56.49)\end{array}$ & $\begin{array}{c}299 \\
(55.68)\end{array}$ & 0.0221 & $\begin{array}{c}574 \\
(62.66)\end{array}$ & $\begin{array}{l}247 \\
(56.39)\end{array}$ & $\begin{array}{c}255 \\
(54.72)\end{array}$ & 0.0073 \\
\hline Physician-staffed & $\begin{array}{c}554 \\
(39.71)\end{array}$ & $\begin{array}{c}190 \\
(44.71)\end{array}$ & & $\begin{array}{l}335 \\
(37.64)\end{array}$ & $\begin{array}{l}171 \\
(43.51)\end{array}$ & $\begin{array}{c}238 \\
(44.32)\end{array}$ & & $\begin{array}{c}342 \\
(37.34)\end{array}$ & $\begin{array}{l}191 \\
(43.61)\end{array}$ & $\begin{array}{c}211 \\
(45.28)\end{array}$ & \\
\hline
\end{tabular}

The analysis showed a positive correlation between the gestational week and the number of pregnancies, the number of deliveries, and heart rate and respiration rate values. In contrast, there was a weak correlation between the gestational week and the saturation value. The analysis also showed a strong positive correlation between the number of pregnancies and the number of deliveries, and a weak positive correlation between the number of pregnancies and the MAP value (mean arterial pressure). Furthermore, there was a weak positive correlation between the number of deliveries and the MAP value. The above-mentioned correlations were statistically significant $(p<0.05)$. Detailed data are presented in Table 5.

Table 5. Analysis of the correlation between gestational week, number of pregnancies and number of previous deliveries and selected variables.

\begin{tabular}{|c|c|c|c|c|c|c|c|c|c|c|c|}
\hline \multirow{2}{*}{ Variables } & \multicolumn{2}{|c|}{$\begin{array}{l}\text { Gestational } \\
\text { Week }\end{array}$} & \multirow{2}{*}{$p$-Value } & \multicolumn{3}{|c|}{$\begin{array}{l}\text { Number of } \\
\text { Pregnancies }\end{array}$} & \multirow{2}{*}{$p$-Value } & \multicolumn{3}{|c|}{$\begin{array}{c}\text { Number of Previous } \\
\text { Deliveries }\end{array}$} & \multirow{2}{*}{$p$-Value } \\
\hline & $\begin{array}{c}\leq 13 \\
\text { Weeks }\end{array}$ & $\begin{array}{l}14 \text { or } \\
\text { More }\end{array}$ & & 1st & 2nd & $\begin{array}{l}\text { 3rd or } \\
\text { More }\end{array}$ & & None & $1-2$ & $\begin{array}{l}3 \text { or } \\
\text { more }\end{array}$ & \\
\hline $\begin{array}{l}\text { Number of } \\
\text { pregnancies }\end{array}$ & \multicolumn{2}{|c|}{$\mathrm{r}=0.182$} & 0.0000 & \multicolumn{3}{|c|}{-} & - & & - & & - \\
\hline $\begin{array}{c}\text { Number of previous } \\
\text { deliveries }\end{array}$ & \multicolumn{2}{|c|}{$\mathrm{r}=0.159$} & 0.0000 & \multicolumn{3}{|c|}{$\mathrm{r}=0.945$} & 0.0000 & & - & & - \\
\hline \multicolumn{12}{|c|}{ Selected physical examination findings } \\
\hline Heart rate & \multicolumn{2}{|c|}{$r=0.068$} & 0.0048 & \multicolumn{3}{|c|}{$\mathrm{r}=0.020$} & 0.3963 & \multicolumn{3}{|c|}{$r=0.010$} & 0.6910 \\
\hline MAP & \multicolumn{2}{|c|}{$r=0.040$} & 0.0978 & \multicolumn{3}{|c|}{$\mathrm{r}=0.072$} & 0.0031 & \multicolumn{3}{|c|}{$\mathrm{r}=0.057$} & 0.0196 \\
\hline Respiration rate & \multicolumn{2}{|c|}{$r=0.055$} & 0.0225 & \multicolumn{3}{|c|}{$r=0.026$} & 0.2857 & \multicolumn{3}{|c|}{$r=0.024$} & 0.3257 \\
\hline Saturation & \multicolumn{2}{|c|}{$\mathrm{r}=-0.058$} & 0.0185 & \multicolumn{3}{|c|}{$r=0.004$} & 0.8836 & \multicolumn{3}{|c|}{$r=0.004$} & 0.8819 \\
\hline
\end{tabular}

\section{Discussion}

Pregnancy loss and its impact, mainly on the psychological health of women, represents a major challenge for the public health sector and health care professionals providing care to patients in this exceptional time $[7,15]$. In addition, patients experiencing symptoms that can potentially indicate a threat to the pregnancy may seek assistance by various 
means: reporting to a clinic or a hospital emergency department, or placing an emergency call $[1,4,9,10,13]$. These aspects motivated us to investigate the characteristics of EMS team interventions in cases of suspected miscarriage, or pregnancy loss up to the 22nd gestational week.

In Ontario, most pregnant patients seen at the emergency department were under 25 years old, nulliparous, and in the first trimester of pregnancy [16]. In a study by Miller et al. (2019), women reporting at the emergency department with a miscarriage were mostly under 30, pregnant for a second or subsequent time, had given birth at least once before, and had a history of miscarriage [8]. In our study, EMS teams were dispatched mainly to women with suspected miscarriage who were 30 years old on average, primiparous, in the first trimester, and had no history of miscarriage. The most commonly reported symptom was vaginal bleeding. Notably, vaginal bleeding in early pregnancy occurs in approximately one in four pregnant women, and half of these cases end in miscarriage [4,5]. Baird et al. (2018) reported the experiences of women with miscarriage in an emergency room. The most common symptom reported by the patients was spotting, and most patients sought assistance due to concerns about the associated health risk [17]. In turn, a Turkish study demonstrated that in women who experienced bleeding in pregnancy, the bleeding was most commonly described as minor. Most patients initially waited for it to stop, and only later sought help at an emergency department [18].

Cox et al. (2020) presented a study on the early pregnancy care model. In the analyzed period, between July 2018 and February 2019, 25 pregnant patients were transported from Early Pregnancy Assessment Units to the John Radcliffe hospital, mainly due to ectopic pregnancy or heavy bleeding. The number of transports was the highest in July [19]. According to our findings, EMS team interventions concerning cases of suspected pregnancy loss most often took place in the winter, during the daytime, with urgency code 2 , and in urban areas. A study by Wierzbik-Strońska et al. (2020) on the characteristics of EMS team interventions in southern Poland also demonstrated that the teams were most often dispatched to patients with various health problems during the prenatal, perinatal, and postpartum periods in urban areas [20]. In turn, Strehlow et al. (2016) and Bills et al. (2018) reported that most EMS interventions for pregnant patients were performed in rural areas [21,22]. Similarly, Varner et al. (2020) reported that most pregnant patients seen at the emergency department were rural residents [16]. Furthermore, Strehlow et al. (2016) found that the emergency medical procedures performed by EMS team members most commonly included the measurement of primary vital signs-heart rate, blood pressure, and respiration rate [21], which is similar to our findings, with blood pressure measurement being performed in most cases. It needs to be noted that the study material indicates that medical emergency procedures, such as the measurement of primary vital signs, were not carried out in all the pregnant women. This may suggest that, indeed, these procedures were not performed or that this aspect was not included in the medical documentation filled in by EMS team members due to the need for urgent transport of the patient to hospital. Nevertheless, this situation shows that EMS team members should complete medical records with greater diligence. The results of our study revealed that the more advanced the gestational week, the higher the number of previous deliveries and pregnancies, and the higher the heart rate and respiration rate values. Conversely, the more advanced the pregnancy, the lower the saturation value. The analysis also demonstrated that a higher number of pregnancies was associated with a higher number of deliveries and a higher MAP value, and that a higher number of previous deliveries was associated with a higher MAP value obtained in the examination performed by EMS. In our study, the mean duration of EMS team interventions for pregnant patients was also longer when the teams were dispatched to rural areas than to urban ones, which is similarly corroborated by Strehlow et al. (2016) [21]. Analyzing the health problems of pregnant women requiring EMS assistance, Freitas et al. (2020) found that the most common reason for the call was labor, followed by miscarriage, preeclampsia, and vaginal bleeding. They also reported that multiparous women and those in the third trimester of pregnancy were more likely to 
call Mobile Emergency Care Services [23]. By comparison, our study demonstrated that in the case of rural areas, EMS teams were more often dispatched to women in the third or subsequent pregnancy and those who had a history of three or more deliveries.

One important aspect of pregnancy loss involves its risk factors. Among the many risk factors for miscarriage, researchers have highlighted the mother's age, socio-economic standing, nutritional status, and substance use; history of obstetric problems such as miscarriage, premature labor, cesarean section, or gestational diabetes mellitus; performing physical labor requiring heavy lifting; stress; infections; and hormonal factors [24-27]. Both maternal age above 35 years and multiple previous deliveries increase the risk of miscarriage [24]. We found that the number of EMS team interventions was related to the age of the woman, gestational age, the number of pregnancies, and the number of deliveries.

Our study is the first retrospective analysis of all calls registered by the National Monitoring Center of Emergency Medical Services in Poland, which has allowed for gathering reliable data on EMS team interventions in cases of women with suspected miscarriage. Moreover, it complements our previous study on vaginal bleeding in pregnant women as a reason for EMS team intervention [28].

Our analyses showed that EMS teams were more often dispatched to primiparous women, in the third trimester of pregnancy, nulliparous women, and women who experienced miscarriage, and that the dominating symptoms were vaginal bleeding and abdominal pain. Interestingly, pregnant women living in rural areas were assigned code 1, which means that an urgent dispatch of an EMS team was required, with the shortest possible time of reaching the location of the event, because a health-threatening emergency requires an immediate use of medical emergency procedures. A threat to pregnancy requires immediate action. If the patient is at home, this means calling the EMS, followed by rapid transport to hospital and further professional management. It is estimated that about $10-15 \%$ of all pregnancies in Poland end with miscarriage. Data collected based on reports about the general activity of hospitals indicate that in Poland the number of women who miscarried in 2017 was over 40,000, in 2018 - nearly 39,000, and in 2019-over 39,000 . Looking at the scale of the miscarriage prevalence, it is crucial to apply immediate interventions focused on maintaining the pregnancy [29].

This study has certain limitations. The analysis only includes information from the EMS electronic medical records. We do not have information on the follow-up care provided to the patients after they had been transferred to hospital or on patient condition in cases where the woman was left in place. Furthermore, we do not have any knowledge on the patient health or obstetric status with regard to the suspected miscarriage after the EMS team interventions have taken place, which makes it impossible to analyze the entire process of care provided to these women. However, these limitations do not affect the quality of the study performed.

The results of our study indicate that it is necessary to conduct further research on health problems in pregnant women with suspected miscarriage to better understand the issue in question. Furthermore, research should be conducted in the area of EMS team members' preparation to provide assistance to pregnant women, especially in cases of high-risk pregnancies. As a result, pregnant women will receive better care, including that provided by EMS team members who are responsible for offering medical assistance on site.

\section{Conclusions}

EMS teams most commonly intervened in cases of pregnant women with suspected miscarriage who were at a mean age of 30 years, primiparous, and in the first trimester of pregnancy. The most reported symptom was vaginal bleeding. Most interventions were carried out in the winter, during the daytime, in urban areas, with urgency code 2 , and included patient transport to hospital. 
The present study addresses very important issues concerning the characteristics of Polish suspected miscarriage cases handled by different EMS team types (physicianstaffed vs. non-physician staffed), in different areas (urban vs. rural area), and concerning patients in a different obstetric situation (gestational week, gravidity, parity). It points to a need for further studies in this field and for gestational health promotion activities to be implemented, specifically including actions to reduce the risk of early pregnancy loss.

Author Contributions: Conceptualization, E.R.; methodology, E.R.; formal analysis, P.R.; resources, R.G.; writing-original draft preparation, E.R., A.B.; writing—review and editing, G.B., M.F., E.R.; project administration, E.R. All authors have read and agreed to the published version of the manuscript.

Funding: This research received no external funding.

Institutional Review Board Statement: Ethical review and approval were waived for this study, due to the Bioethics Committee of the Medical University of Warsaw decided that conducting the study does not require the consent of this committee-the retrospective nature of the study (statement AKBE/104/2021).

Informed Consent Statement: Not applicable.

Data Availability Statement: The data presented in this study are available on request from the corresponding author.

Conflicts of Interest: The authors declare no conflict of interest.

\section{References}

1. Walter, M.A.; Alvarado, M.S. Clinical Aspects of Miscarriage. MCN Am. J. Matern. Child Nurs. 2018, 43, 6-12. [CrossRef]

2. Norton, W.; Furber, L. An exploration of how women in the UK perceive the provision of care received in an early pregnancy assessment unit: An interpretive phenomenological analysis. BMJ Open. 2018, 8, e023579. [CrossRef]

3. Emond, T.; de Montigny, F.; Guillaumie, L. Exploring the needs of parents who experience miscarriage in the emergency department: A qualitative study with parents and nurses. J. Clin. Nurs. 2019, 28, 1952-1965. [CrossRef] [PubMed]

4. Punches, B.E.; Johnson, K.D.; Acquavita, S.P.; Felblinger, D.M.; Gillespie, G.L. Patient perspectives of pregnancy loss in the emergency department. Int. Emerg. Nurs. 2019, 43, 61-66. [CrossRef]

5. Çevik Ateş, A.; Topatan, S. The relationship between support systems and anxiety in couples admitted to the emergency department with vaginal bleeding. Int. Emerg. Nurs. 2019, 46, 100781. [CrossRef]

6. MacWilliams, K.; Hughes, J.; Aston, M.; Field, S.; Moffatt, F.W. Understanding the Experience of Miscarriage in the Emergency Department. J. Emerg. Nurs. 2016, 42, 504-512. [CrossRef]

7. Freeman, A.; Neiterman, E.; Varathasundaram, S. Women's experiences of health care utilization in cases of early pregnancy loss: A scoping review. Women Birth. 2021, 34, 316-324. [CrossRef]

8. Miller, C.A.; Roe, A.; McAllister, A.; Meisel, Z.F.; Koelper, N.; Schreiber, C.A. Patient Experiences With Miscarriage Management in the Emergency and Ambulatory Settings. Obstet. Gynecol. 2019, 134, 1285-1292. [CrossRef] [PubMed]

9. de Montigny, F.; Verdon, C.; Dubeau, D.; Devault, A.; St-André, M.; Tchouaket Nguemeleu, É.; Lacharité, C. Protocol for evaluation of the continuum of primary care in the case of a miscarriage in the emergency room: A mixed-method study. BMC Pregnancy Childbirth. 2017, 17, 124. [CrossRef] [PubMed]

10. Adolfsson, A.; Tullander-Tjörnstrand, K.; Larsson, P.G. Decreased need for emergency services after changing management for suspected miscarriage. Acta Obstet. Gynecol. Scand. 2011, 90, 921-923. [CrossRef]

11. Yang, J.; Savitz, D.A.; Dole, N.; Hartmann, K.E.; Herring, A.H.; Olshan, A.F.; Thorp, J.M., Jr. Predictors of vaginal bleeding during the first two trimesters of pregnancy. Paediatr. Perinat. Epidemiol. 2005, 19, 276-283. [CrossRef] [PubMed]

12. Rashad, W.A.; Essa, R.M. Women's Awareness of Danger Signs of Obstetrics Complications. J. Am. Sci. 2010, 6, 1299-1306. [CrossRef]

13. Emergency Medicine Act of September 8, 2006. J. Laws 2020, 882. Available online: https:/ / isap.sejm.gov.pl/isap.nsf/download. xsp/WDU20200000882/T/D20200882L.pdf (accessed on 4 August 2021). (In Polish).

14. System Wspomagania Dowodzenia Państwowego Ratownictwa Medycznego (SWD PRM)/National Monitoring Center of Emergency Medical Services. Available online: https://www.gov.pl/web/zdrowie/system-wspomagania-dowodzeniapanstwowego-ratownictwa-medycznego-swd-prm- (accessed on 4 August 2021) (In Polish).

15. Dhaded, S.M.; Somannavar, M.S.; Jacob, J.P.; McClure, E.M.; Vernekar, S.S.; Yogesh Kumar, S.; Kavi, A.; Ramadurg, U.Y.; Moore, J.L.; Wallace, D.P.; et al. Early pregnancy loss in Belagavi, Karnataka, India 2014-2017: A prospective population-based observational study in a low-resource setting. Reprod. Health 2018, 15 (Suppl. 1), 95. [CrossRef]

16. Varner, C.E.; Park, A.L.; Little, D.; Ray, J.G. Emergency department use by pregnant women in Ontario: A retrospective population-based cohort study. CMAJ Open. 2020, 8, E304-E312. [CrossRef] 
17. Baird, S.; Gagnon, M.D.; de Fiebre, G.; Briglia, E.; Crowder, R.; Prine, L. Women's experiences with early pregnancy loss in the emergency room: A qualitative study. Sex Reprod. Healthc. 2018, 16, 113-117. [CrossRef] [PubMed]

18. Koşum, Z.; Yurdakul, M. Factors affecting the use of emergency obstetric care among pregnant women with antenatal bleeding. Midwifery 2013, 29, 440-446. [CrossRef]

19. Cox, R.; Khalid, S.; Brierly, G.; Forsyth, A.; McNamara, R.; Heppell, V.; Granne, I. Implementing a community model of early pregnancy care. BMC Health Serv. Res. 2020, 20, 664. [CrossRef]

20. Wierzbik-Strońska, M.; Nadolny, K.; Grabarek, B.O.; Boroń, D. Characteristics of the Intervention of Emergency Medical Teams in the Southern part of Poland in 12-Month Observation. Wiad. Lek. 2020, 73, 1632-1636. [CrossRef] [PubMed]

21. Strehlow, M.C.; Newberry, J.A.; Bills, C.B.; Min, H.E.; Evensen, A.E.; Leeman, L.; Pirrotta, E.A.; Rao, G.V.; Mahadevan, S.V. Characteristics and outcomes of women using emergency medical services for third- trimester pregnancy-related problems in India: A prospective observational study. BMJ Open 2016, 6, e011459. [CrossRef]

22. Bills, C.B.; Newberry, J.A.; Darmstadt, G.; Pirrotta, E.A.; Rao, G.V.R.; Mahadevan, S.V.; Strehlow, M.C. Reducing early infant mortality in India: Results of a prospective cohort of pregnant women using emergency medical services. BMJ Open 2018, 8 , e019937. [CrossRef]

23. Freitas, V.C.A.; Quirino, G.S.; Giesta, R.P.; Pinheiro, A.K.B. Clinical and obstetric situation of pregnant women who require prehospital emergency care. Rev. Bras. Enferm 2020, 73 (Suppl. 4), e20190058. [CrossRef]

24. Zhou, H.; Liu, Y.; Liu, L.; Zhang, M.; Chen, X.; Qi, Y. Maternal pre-pregnancy risk factors for miscarriage from a prevention perspective: A cohort study in China. Eur. J. Obstet. Gynecol. Reprod. Biol. 2016, 206, 57-63. [CrossRef] [PubMed]

25. Feodor Nilsson, S.; Andersen, P.K.; Strandberg-Larsen, K.; Nybo Andersen, A.M. Risk factors for miscarriage from a prevention perspective: A nationwide follow-up study. BJOG 2014, 121, 1375-1384. [CrossRef]

26. Magnus, M.C.; Wilcox, A.J.; Morken, N.H.; Weinberg, C.R.; Håberg, S.E. Role of maternal age and pregnancy history in risk of miscarriage: Prospective register based study. BMJ 2019, 20, 1869. [CrossRef]

27. Oliveira, M.T.S.; Oliveira, C.N.T.; Marques, L.M.; Souza, C.L.; Oliviera, M.V. Factors associated with spontaneous abortion: A systematic review. Rev. Bras. Saude Mater. Infant. 2020, 20, 361-372. [CrossRef]

28. Rzońca, E.; Bień, A.; Gotlib, J.; Gałązkowski, R. Bleeding during pregnancy as a reason for interventions by emergency medical services teams in Poland. Ann. Agric. Environ. Med. 2021. [CrossRef]

29. Rozkrut, D. Demographic Yearbook of Poland; Statistics Poland: Warsaw, Poland, 2020. 